\title{
ACCOUNTABILITY OF REGIONAL OFFICIALS OF SIDOARJO REGENCY IN THE DISTRIBUTION OF GROCERIES DURING THE COVID-19 PANDEMIC
}

\author{
Akmal Maulana N.M ${ }^{1}$, Andre Purnairawan ${ }^{2}$, Sholahuddin Al-Fatih ${ }^{3 *}$ Jamil $^{4}$ \\ $1,2,3^{*}$ Faculty of Law, University of Muhammadiyah Malang, Indonesia, \\ ${ }^{4}$ Faculty of Law, Universitas Bhayangkara Surabaya, Indonesia \\ salfatih@umm.ac.id*(corresponding).
}

\begin{abstract}
This article aims to analyze the distribution of free groceries in the Sidoarjo regency during the Covid-19 pandemic. Free groceries program for citizens in almost every year by the local government. But it is slightly different in pandemic times like today, where the free Groceries program is more often done and on a large scale. One of them is carried out by the Sidoarjo Regency Government, East Java. Keep in mind that the thing that is affected by the outbreak of the Covid-19 Virus is an economic factor, which makes most people lose their eyes that make the weakening of the economic system in Indonesia no exception in the Sidoarjo Regency itself. This paper takes socio-legal research to find out the problem of the distribution of free groceries in Sidoarjo regency. The results of this study look at the extent of the accountability of the Sidoarjo Regency government with the Covid-19 outbreak in the community, namely from the start of the distribution of free food so that it is expected to provide more concrete results. Sidoarjo Regency government program is expected to be applied in the early stages of formulation, implementation, and evaluation of public policy.
\end{abstract}

Keywords: Distribution of Groceries; Government Accountability; Sidoarjo Regency

\section{INTRODUCTION}

As the 2019 Coronavirus (Covid-19) outbreak spread in more than 210 countries around the world, more than 3,000,000 cases resulted in more than 200,000 deaths and 878,000 patients recovering (RA et al., 2020). The Covid-19 outbreak first appeared in Wuhan City, China in December 2019 and was designated a Covid-19 Pandemic by the World Health Organization (WHO) on March 11, 2020 (Al-Fatih \& Aulia, 2021). Pandemic corona virus disease 2019 is pneumonia that hit the world today. In Indonesia this virus has taken a lot of casualties and has crippled various sectors including the economy (Wijaya \& Herwastoeti, 2022). The Covid-19 pandemic has entered Indonesia since the beginning of 2020 (Kartikawati, 2021). Indonesia with a population of more than 270 million is inevitable to be a country exposed to the corona virus (Al-Fatih et al., 2020). It was first discovered in two residents of Depok, West Java in early March.

Based on data from the Covid-19 Handling Task Force in Indonesia until April 28, 2020 the number of citizens who tested positive for the coronavirus reached 9,771 people, 1,391 
recovered and 784 died (Al-Fatih, 2020a). Indonesia has a big challenge with the covid-19 pandemic because it has a very large and widespread population and in fact has the third largest population in the world. Many ways and efforts have been made by the government in tackling this pandemic where the government has issued many policies as a responsive first step to minimize the wider spread of this virus (Al-Fatih, 2021). In addition to public health and safety policies, the Government also aids its citizens who are affected by the outbreak of this virus.

The form of assistance provided by the Government is diverse, one of which is done by the Sidoarjo Regency Government, namely groceries assistance to its citizens. But in terms of distribution, we must first examine from various sectors whether the distribution is on target to citizens in need or there are other things that deviate. Basically, supervision is carried out to avoid the possibility of irregularities or abuses of the goals to be achieved, because with supervision it can find out the extent to which the government has carried out its policies and whether there is abuse of a job. According to Rahman Mulyawan, supervision is the process of observation of the implementation of all organizational activities to ensure that all work that is being carried out goes according to the predetermined plan (Bate'e \& Gea, 2018). In general, supervision can determine what will be achieved, to be implemented and whether in accordance with applicable standards. As a result of the outbreak of this virus in Sidoarjo which became the $2^{\text {nd }}$ largest in East Java, the Government took this event very seriously and made a consensual to its citizens who lost a lot of livelihoods that made it difficult for its citizens to buy necessities such as their daily food. Supervision of distribution is very important because in terms of distribution is vulnerable to abuse (Anggreni \& Subanda, 2020).

Distribution is an activity carried out to convey products from the manufacturer to the intended consumer. One example of distribution that needs to be supervised is the distribution of groceries carried out by the Sidoarjo Regency Government (Nugroho, 2020). Sidoarjo Regency consisting of 18 subdistricts and 353 villages and inhabited by about 2 million people makes the distribution of groceries package assistance by the Government may have a little difficulty, but here the Government gets the data of underprivileged citizens through data recorded in the Integrated Social Welfare Data (DTKS) in the Sidoarjo Social Service (Setiawan, 2020).

The data obtained by the Sidoarjo Provincial Government is about 135 thousand underprivileged residents spread across 18 sub-districts and 353 out of villages. But in addition to the distribution of 135 thousand packages of this groceries there are another 24 thousand packages of groceries for micro-business workers and several other elements affected by the coronavirus outbreak (Covid-19). But not all this groceries package assistance comes from APBD but there are also some from the help of entrepreneurs as well (Poernomo, 2020).

It should be noted that the system and mechanism of distribution of groceries that applies in Sidoarjo Regency is open and passive. What is meant passive here is not explained how much received or what groceries received by the citizens of Sidoarjo, because the citizens only receive so in the form of parcels that contain packages of groceries, and the citizen does not know whether if he has registered as an underprivileged citizen in the Village the data will be recorded in the Integrated Social Welfare Data (DTKS). Things like this should be a concentration of supervision in the process of distributing the aid package. And what is meant openly here is the distribution of this groceries package is done directly by the Government, Covid-19 Task Force 
and assisted by the Sidoarjo Regency Police so that the residents only need to wait at their homes for the package of groceries to be given (Ishak et al., 2017).

This system of distribution of groceries by the Government that is open and passive could make mistakes in its distribution such as distribution errors to citizens who do not really need the package, and it could be citizens who have received previous groceries packages from other programs and finally get more groceries packages from the Government that can cause social jealousy among citizens with other citizens. In other words, it is a distribution system like this that makes mistakes in the process of distributing it and creates social jealousy. But with an outbreak like this and with the number of citizens who continue to surge to the economic fall makes this increasingly a difficult job to do by the Government. The absence of a transparent surveillance system that makes this program seem not to run according to the original goal, namely only citizens who need it. But the difficulty in distributing groceries packages may have been the consensus of the Government since before the program was held. And the supervision team should have been formed so that the intended target is in accordance with the initial objectives of the Provincial Government.

From the above exposure, more research is needed to find out what causes if there is less supervision from the Government in the distribution of thousands of packages of these groceries, and the basic problems that make the uneven distribution of these groceries' packages to the citizens. Based on some of the descriptions that have been described above appear some of the problems that will be discussed as follows: a) Why is there a need for a supervisory function in the distribution of this groceries aid, and; b) How does the distribution of free food packages affect the availability of groceries in the market.

\section{METHODOLOGY}

The research methods used in this journal are descriptive approach methods and qualitative methods with techniques for analysis of literature studies (Zain et al., 2021) in the field of Local Government science to develop concepts that are in accordance with the supervision of the Government program. Data collection techniques by tracing various data sources in the form of journals from online media as secondary data sources to be processed, research results are analyzed first based on policy research and described in the form of litelatur studies and with data interpretation techniques (Hakim, 2021) (Al-Fatih, 2020b). Descriptive and qualitative research methods are used in the framework of natural object research, here researchers, government and residents of Sidoarjo Regency will be key, and this study will put more emphasis on what local officials do to help their communities affected by Corona Virus Disease 2019 (Covid-19).

\section{RESULTS AND DISCUSSION}

In general, the definition of subsidy is an obligation carried out by the government of a local government to its people who are entitled to receive it. The idea of the Sidoarjo Government about distributing thousands of packages of food to its citizens is a public policy innovation, especially during this pandemic period, where public policy innovation is needed. Innovation is a new idea that is felt by individuals or society in general. In discussing crisis management policies during the pandemic period in Sidoarjo Regency, one of them is by distributing free food packages to its citizens (Bate'e \& Gea, 2018). 
The actions of the Sidoarjo Government are not only a public policy during the pandemic period, but also a program like Non-Cash Food Assistance which is food social assistance in the form of non-cash from through the specified mechanism. Another goal of this Non-Cash Food Assistance program is to reduce the burden of KPM (Beneficiary Family) expenditure through partial fulfillment of food needs, provide more balanced nutrition to KPM (Beneficiary Family), improve the accuracy of targets and acceptance time.

The notion of self-supervision has been put forward by many authors in the field of management in books. For example, the work of Erni T. Sule and Saefullah Kurniawan (2005), among them is Schermerhorn (2002) in his book written that supervision as a process in determining measures of performance and taking actions that can support the achievement of expected results in accordance with the performance that has been determined (Bate'e \& Gea, 2018). Based on them, Schermerhorn emphasized that the supervisory function lies in setting a standard of performance and actions that must be taken in order to achieve the performance that has been set.

Schermerhorn's explanation is the same as the notion of supervision according to Stoner, Freeman, and Gilbert (2000) where their definition of supervision is control is the process of ensuring that actual activities conform the planned activities (Thomas et al., 2004). So, supervision is a process to ensure that all activities carried out at that time are in accordance with what has been planned. Moreover, Stoner, Freeman, and Gilbert (2000) are still in their book Erni T. Sule (2005) proposing the function of supervision as a systematic effort to set performance standards with planning objectives, to design information feedback systems, to compare actual performance with these predetermined standards, to determine whether there are any deviations and to measure their significance, and to take any action required to assure that all corporate objectives.

This means that surveillance is a systematic effort to establish performance standards and planned objectives, design feedback information systems, compare performance achieved with pre-established standards, determine whether there are deviations and significance levels of such deviations, and take the necessary actions to ensure that all company resources are used effectively and efficiently in achieving their objectives. Although what is explained here is a form of supervision that is more intended for a company, but it is also appropriate when used in the concept of a government, because both a company and a government equally have a clear structural form. The purpose of the surveillance function itself is (Sururi, 2017):

1. Environmental Adaptation. The first purpose of this supervisory function is so that a government can continue to adapt to changes that occur in the environment, both the internal environment and the external environment.

2. Minimize errors. When a government conducts activities to find producers for example, the government hopes that mistakes are minimal both from the producer side and from the government's own side.

3. Minimize costs. The function of supervision through the setting of certain standards in minimizing errors in production, for example, will be able to minimize the costs that must be incurred by a government.

4. Anticipate the Complexity of External Organizations. The last purpose of the supervisory function is so that a government can anticipate various activities of external organizations 
that may benefit from the running of programs carried out by this government, which may also be able to make something undesirable to the community later. In order for the four objectives of the supervisory function to be better understood, the steps are set through the supervision process so that there is a link between what is done by the Sidoarjo Government and the supervisory function will be more understandable, and among the community also does not appear any form of social jealousy or other things that cause division.

Determining of the availability of groceries materials in the market today, the number of attributes possessed by groceries materials or products that can be assessed by organoleptic techniques. These attributes include parts of appearance, color, texture, taste and smell (Kramer \& Twigg, 1983). In the opinion of Hubeis (1994), quality is considered a degree of consumer acceptance of products consumed repeatedly (uniform or consistent in standards and specifications), especially its organoleptic properties. Quality can also be considered as satisfaction (of needs and prices) obtained by consumers from the integrity of products produced by producers. Based on ISO/DIS 8402 - 1992, quality is defined as a comprehensive characteristic of a form whether it is a product, activity, process, organization or human being, demonstrating its ability to meet predetermined needs (Adawiyah et al., 2017). Kramer and Twigg (1983) have classified the quality characteristics of food into two groups, namely: (1) physical characteristics or visible characteristics, including appearance i.e. color, size, shape and physical disability; kinestics are texture, viscosity and consistency; Flavor is the sensation of a combination of smell and taste, and (2) hidden characteristics, namely nutritional value and microbiological safety. Quality is different from quantity. If you look at the number of goods that will be distributed by the Government with the amount that is on the part of the producer does not seem to be a problem of availability vacancies in various stores or markets for groceries, because the need for food during a pandemic like this is also needed by the wider community. The existence of a government program called PSBB (Large-Scale Social Restrictions) and an appeal for WFH (Work From Home) to keep people indoors and choose to keep clean such as cooking food to eat alone in their homes (Cahyono, 2015).

\section{CONCLUSION}

Based on the results and discussions above, it is known how the Sidoarjo Provincial Government's policy forms in dealing with the crisis during the covid-19 pandemic. The policy is the distribution of thousands of packages of food to underprivileged citizens who may be able to suppress the crisis that occurred. But with the policy in the form of distribution there is a form of supervision of all factors in order to create transparency between the Government and society and the absence of any form of social jealousy towards fellow people. The government policy also has an impact on the existence of groceries in the market, but that does not mean that groceries in the market is exhausted and the Government already has ways to keep increasing the stock of groceries sold in the market.

\section{REFERENCES}

Adawiyah, R., Faoziyah, S., \& Suryatna, Y. (2017). Implementasi Program Beras Untuk Keluarga Miskin (Raskin) Dan Dampaknya Bagi Keluarga Di Kelurahan Kenanga Kecamatan Sumber Kabupaten Cirebon. Jurnal Pengembangan Komunitas, 1(2), 1-14. https://doi.org/10.24235/empower.v1i2.1496 
Al-Fatih, S. (2020a). Basmi Covid-19 Melalui Jalur Legislasi. Bhirawa. https://www.harianbhirawa.co.id/basmi-covid-19-melalui-jalur-legislasi/

Al-Fatih, S. (2020b). Penerapan Threshold dalam Pemilu Menurut Perspektif Gustav Radbruch dan Hans Kelsen. Audito Comparative Law Journal (ACLJ), 1(2), 78-84. https://doi.org/10.22219/audito.v1i2.13973

Al-Fatih, S. (2021). Urgensi Sosialisasi Pilkada Sehat di Tengah Pandemi Covid-19 di Wilayah Malang Raya. Jurnal Dedikasi Hukum, 1, 45-57. https://doi.org/https://doi.org/10.2229/jdh.v1i1.16314

Al-Fatih, S., Ahsany, F., \& Alamsyah, A. F. (2020). Legal Protection of Labor Rights During the Coronavirus Disease 2019 (Covid-19) Pandemic. Jurnal Pembaharuan Hukum, 7(2), 100 115. https://doi.org/10.26532/jph.v7i2.10975

Al-Fatih, S., \& Aulia, F. I. (2021). Tanggung Jawab Negara Dalam Kasus Covid-19 Sebagai Perwujudan Perlindungan HAM (The State's Responsibility in the Case of COVID-19 As a Realization of the Protection of Human Rights). Jurnal HAM, 12(3), 349-366. https://doi.org/10.30641/ham.2021.12.349-366

Anggreni, N. O., \& Subanda, I. N. (2020). Implementasi Kebijakan Penyaluran Hibah dan Bantuan Sosial Kemasyarakatan di Kabupaten Buleleng. Jurnal Ilmiah Manajemen Ekonomi Dan Akuntansi, 4(2), 98-115. https://doi.org/10.31955/mea.vol4.iss2.pp98-115

Bate'e, M. M., \& Gea, N. E. (2018). Efektivitas Fungsi Pengawasan Dalam Pendistribusian Raskin Di Desa Tetehosi I Kecamatan Gunungsitoli Idanoi. Jesya (Jurnal Ekonomi \& Ekonomi Syariah), 1(2), 92-98. https://doi.org/10.36778/jesya.v1i2.22

Cahyono, A. (2015). Implementasi Program Beras Miskin (Raskin) Dalam Meningkatkan Kesejahteraan Masyarakat Rumah Tangga Miskin Desa Montor Kecamatan Banyuates Kabupaten Sampang. Jurnal Untag Sby, 1(1), 11-21. https://doi.org/10.30996/jpap.v1i02.685

Hakim, H. M. I. el. (2021). Pemantapan Dimensi Etika dan Asas sebagai Penguatan Sistem Hukum Lingkungan di Indonesia. Audito Comparative Law Journal, 2(3), 155-169. https://doi.org/10.22219/aclj.v2i3.18041

Ishak, D., Maolani, D. Y., \& Engkus. (2017). Konsep kinerja dalam studi organisasi publik. JISPO: Jurnal Ilmu Sosial Idan Lmu Politik, 7(2), 101-120. https://doi.org/10.15575/jp.v7i2.2274

Kartikawati, D. R. (2021). Tanggung Jawab Rumah Sakit terhadap Pemenuhan Hak Pasien pada Masa Pandemi COVID-19. Indonesia Law Reform Journal (ILREJ), 1(3), 318-335. https://doi.org/10.22219/ilrej.v1i3.18223

Kramer, A., \& Twigg, B. (1983). Quality control for the food industry. Avi, 1(2). https://doi.org/10.1177/146642406208200324

Nugroho, A. (2020). Pemkab Sidoarjo Beri Bantuan Sembako untuk 135 Ribu Keluarga. Jawa Pos. https://radarsurabaya.jawapos.com/sidoarjo/14/04/2020/pemkab-sidoarjo-beribantuan-sembako-untuk-135-ribu-keluarga/

Poernomo, S. (2020). Pemkab Sidoarjo Terima Bantuan Sembako Dari Yayasan Tionghoa. RMOL Jatim. http://bpbd.sidoarjokab.go.id/artikel-606.html

RA, M. S., Hamdika, Y., \& Al-Fatih, S. (2020). The Impact of COVID-19 Through the Lens of Islamic Law: An Indonesian Case. Lentera Hukum, 7(3), 267-278. https://doi.org/https://doi.org/10.19184/ejlh.v7i3.18983 
Setiawan, I. (2020). Pemkab Sidoarjo salurkan BST kepada 135 ribu KK Terdampak Covid-19. Antara News. https://www.antaranews.com/berita/1565328/pemkab-sidoarjo-salurkan-bstkepada-135-ribu-kk-terdampak-covid-19

Sururi, A. (2017). Inovasi Kebijakan dalam Perspektif Administrasi Publik Menuju Terwujudnya Good Public Policy Governance. Jurnal Spirit Publik, 12, 14-31. https://doi.org/10.31227/osf.io/6djph

Thomas, T., Jr., J. R. S., \& Dienhart, J. W. (2004). Strategic leadership of ethical behavior in business. Academy of Management Perspectives, 18(2). https://doi.org/10.5465/ame.2004.13837425

Wijaya, H., \& Herwastoeti. (2022). Criminal \& Civil Liability Related to Misuse of Illegal Fintech Customer Data During The Covid-19 Pandemic. Audito Comparative Law Journal (ACLJ), 3(1), 1-9. https://doi.org/10.22219/aclj.v3i1.19873

Zain, H. A., Wiryani, F., \& Hasanah, I. (2021). Kesadaran Hukum Sertifikasi Halal Pelaku Usaha Rumah Makan di Kota Malang. Indonesian Law Reform Journal, 1(1), 122-142. https://doi.org/10.22219/ilrej.v1i1.16130 